\title{
URANIUM SERIES AGES OF CORALS FROM THE UPPER PLEISTOCENE MULEGE TERRACE, BAJA CALIFORNIA SUR, MEXICO
}

\section{EDAD DE CORALES POR SERIES DE URANIO DE LAS TERRAZAS DEL PLEISTOCENO SUPERIOR DE MULEGE, BAJA CALIFORNIA SUR, MEXICO}

\author{
James R. Ashby 1 \\ T.L. Ku 2 \\ John A. Minch 3 \\ 1 Department of Geological Sciences \\ San Diego State University, San Diego, Ca. 92115 \\ Present Adrress: Department of Earth and Space Sciences, \\ University of California, Los Angeles, Ca. 90024 \\ 2 Department of Geological Sciences, \\ University of Southern California, Los Angeles, Ca. 90007 \\ 3 Department of Geology \\ Saddleback College, Mission Viejo, Ca. 92692
}

Ashby R. James, Ku, T.L. and Minch, J.A. Uranium Series Ages of Corals from the Upper Pleistocene Mulegé Terrace, Baja California Sur, Mexico. Edad de corales por series de uranio de las terrazas del Pleistoceno superior de Mulegé, Baja California Sur, Mexico. Ciencias Marinas 14(1): 31-40,1988.

\begin{abstract}
Specimens of Porites califomica contained in the sediments of upper Pleistocene $+12 \mathrm{~m}$ marine terrace deposits devcloped on the east coast of the Baja California (Mexico) peninsula at Mulegé have yielded $230 \mathrm{th} / 234 \mathrm{U}$ dates of $124 \pm 5$ and $144 \pm 7 \mathrm{ka}$ ( \pm one standard deviation). These dates can be assigned to the well-documented late Pleistocene oxygen isotope stage, 5e high sea stand. Differences between theeustatic and present elevation of this terrace indicate average uplift rates since terrace formation of approximately $4 \mathrm{to} 5 \mathrm{~cm}$ per 1000yr, indicating a relative stability and lack of major vertical deformation since the late Pleistocene. This terrace in the Mulege area can now be correlated with other marine terraces throughout the Baja California peninsula and southern California.
\end{abstract}

\section{RESUMEN}

Se fecharon especímenes de Porites califomica contenidos en sedimentos de una terraza de $+12 \mathrm{~m}$ del Pleistoceno superior ubicada en la costa este de la Península de Baja California (Mé-

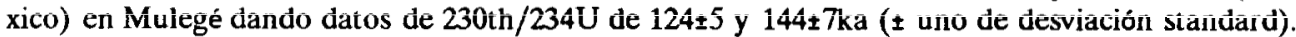
Estos datos pueden asignarse al bien documentado estado de isótopo oxígeno del Pleistoceno tardío Se alto marino. Las diferencias de nivel eustático y presente de estas terrazas indican una razón promedio de elevación desde su formación de aproximadamente 4 o $5 \mathrm{~cm}$ por 1000 años, indicando estabilidad y ausencia de deformación vertical desde el Pleistoceno tardío. Actualmente pueden correlacionarse estas terrazas en el área de Mulegé, como otras terrazas marinas a lo largo de la Península de Baja California y el sur de California. 


\section{INTRODUCTION}

Mulegé is located on the eastern coast of Baja California, Mexico at the northern end of Concepción Bay (Long. 111059'W, Lat. 26053'N; Fig.1). Previous workers in the Concepción Bay area have suggested a late Pleistocene age for the Mulegé Terrace deposits (Beal, 1948; McFall, 1968; Ortleih, 1978). Ashby (1984) and Ashby and Minch (1984) established a late Pleistocene age for these terrace deposits based on a diverse molluscan fauna.

We have obtained $230 \mathrm{Th} / 234 \mathrm{U}$ dates on two samples of the stony coral Porites califomica Verrill collected from sediments upon a $+12 \mathrm{~m}$ terrace surrounding the Mulegé estuary. The two dates are $124 \pm 5$ and $144 \pm 7$ ka ( \pm one standard deviation). To our knowledge, these are the first reported uranium-series dates on coralline material from the east coast of the Baja California peninsula. uranium-series dates have been reported from the west coast of Baja California and from southern California (see Table II). Ortleib (1978), in his reconaissance of Quaternary marine terraces in Baja California, discussed the results of an extensive survey of late Pleistocen terrace elevations throughout the peninsula. However, absolute dating of these terraces was not undertaken.

\section{SAMPLE LOCATIONS}

The two samples of Porites califomica analyzed were among six coral specimens taken from equivalent Pleistocene deposits around Mulegé; the two were selected for dating because they contained less than $2 \%$ calcite. The first sample was collected in situ at San Diego Society of Natural History (SDSNH) locality 3261, the second from a deflation lag deposit from SDSNH locality 3258 (Fig. 1).

\section{SDSNH Locality 3258}

This locality consists of a well-defined, $+12 \mathrm{~m}$ wave-cut terrace incised into and surrounding a small gabbroic pluton (E1 Sombrerito) at the mouth of the Mulegé estuary. The terrace sediments consist of as

\section{INTRODUCCION}

Mulegé se localiza en la costa este de Baja California, México en el extremo norte de Bahía Concepción (Long. 111059'W, Lat. $26^{\circ} 53^{\prime}$ N, Fig. 1). Trabajos previos en el área de la Bahía Concepción han sugerido una edad de Pleistoceno tardío para los depósitos de Terrazas de Mulegé (Beal, 1948; McFall, 1968; Ortleib, 1978). Ashby (1984) y Ashby y Minch (1984) establecieron una edad del Pleistoceno tardío para estos depósitos de terraza con base en una fauna de moluscos diversos.

Obtuvimos datos de $230 \mathrm{Th} / 234 \mathrm{U}$ de dos muestras del coral pétreo Porites califomica Verrill colectadas del sedimento sobre la terraza de $\pm 12 \mathrm{~m}$ que rodea el estuario de Mulegé. Los dos datos son $124 \pm 5$ y $144 \pm 7 \mathrm{ka} \mathrm{(} \pm$ uno de desviacion estandard). Para nuestro conocimiento, este es el primer reporte de datos de series de uranio en material coralino de la costa este de la Península de Baja California. Se han reportado datos de series de uranio de la costa oeste de Baja California y del sur de California (ver Tabla II). En el reconocimiento de las terrazas marinas del Cuaternario, Ortleib (1978), discute los resultados de un estudio detallado de elevación de terrazas del Pleistoceno tardio a lo largo de la Península. Sin embargo no se tiene un fechado absoluto de estas terrazas.

\section{LOCALIZACION DE LAS MUESTRAS}

Las dos muestras analizadas de Porites califomica se seleccionaron de entre seis especímenes de coral tomados de depósitos del Pleistoceno eqivalentes; se seleccionaron para datación porque conten ían menos de $2 \%$ de calcita. La primera fue colectada in situ en la localidad 3261 de la Sociedad de Historia Natural de San Diego(SDSNH), la segunda de un depósito de deflación de la localidad SDSNH 3258 (Fig. 1).

\section{SDSNH Localidad 3258}

Esta localidad consiste en una terraza bien definida, de $\pm 12 \mathrm{~m}$, cortada por oleaje, incluida en un plutón gabroico circundante. (El Sombrerito) en la boca del estuario de 


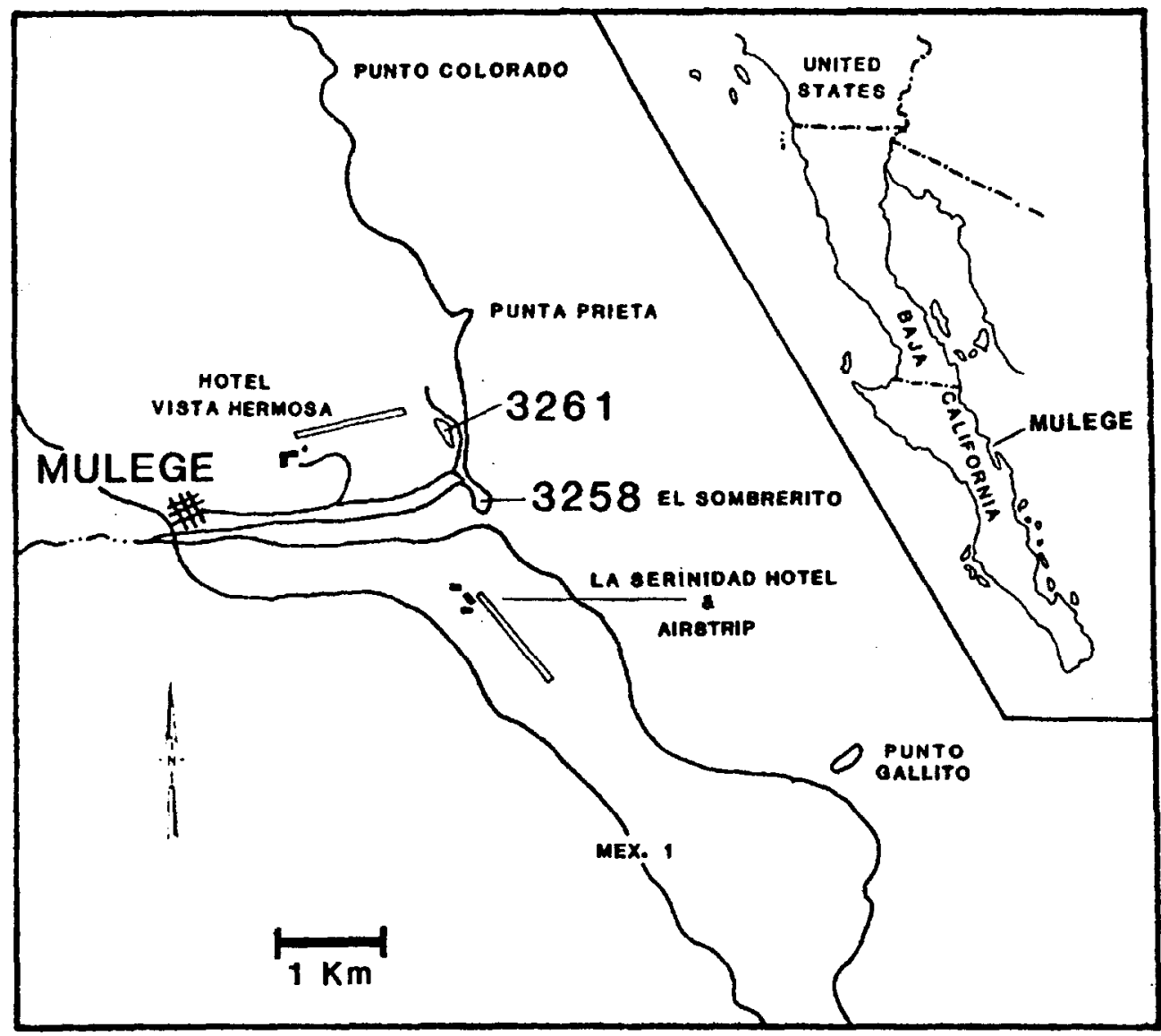

Figure 1. Localization of the study area and sampling places.

Figura 1. Localización del área de estudio y puntos de muestreo.

much as $1 \mathrm{~m}$ of sandy pebble- to cobble-conglomerate. Much of the fossil material collected at this locality was scattered on the surface as a deflation-lag deposit. There are no higher terraces present at this location.

\section{SDSNH Locality 3261}

The second locality is on the southermost portion of the marine terrace exposed along the beach, at the northern edge of the Mulege estuary. The terrace deposits are composed of 1 to $2 \mathrm{~m}$ of buff to gray, poorly indurated, massive to poorly bedded, moderately sorted, silty lithic arkose.
Mulegé. Los sedimentos de la terraza consisten en cuando mucho $1 \mathrm{~m}$ de grava arenosa a conglomerado de cobble. Mucho del material fósil colectado en esta localidad se encontró en la superficie como un depósito de deflación. No hay presencia de terrazas más altas en esta región.

\section{SDSNH Localidad 3261}

La segunda localidad es una de las porciones más hacia el sur, de la terraza marina, expuesta a lo largo de la playa en el extremo norte del estuario de Mulegé. Los depósitos de la terraza están compuestos por 1 a $2 \mathrm{~m}$ de arkosa lítica arcillosa amarillenta a gris, pobremente madura, masiva a pobremente estratificada, moderadamente sorteada. 


\section{EXPERIMENTAL METHODS AND RESULTS}

The $230 \mathrm{Th} / 234 \mathrm{U}$ method of dating marine carbonate materials has been discussed in detail (e.g., Thurber et al., 1965). Our procedures of measuring $234 \mathrm{U}, 238 \mathrm{U}, 230 \mathrm{Th}$, and $232 \mathrm{Th}$ followed those described by $\mathrm{Ku}$ (1965,1968).

Alpha-particle spectrometry was employed, using a multichannel pulse-heigh analyzer with silicon solid-state detectors. The calcite/aragonite ratios were determined from peak intensities of X-ray diffraction patterns. The quoted uncertainties represent standard deviations (one sigma) derived from the counting statistics (Table I). The 230 $\mathrm{Th} / 234 \mathrm{U}$ ages are calculated on the assumption that the carbonate initially contained no 230Th.

\section{DISCUSSION OF RESULTS}

The following criteria indicate that the age values of $124 \pm 5$ and $144 \pm 7 \mathrm{ka}$ for the two coral samples (Table I) represent good age estimates for these terrace deposits in Mulegé. (1) The specimens analyzed are essentially free of recrystallization, as shown by the $>98 \%$ aragonitic mineralogy. (2) The $230 \mathrm{Th} / 232 \mathrm{Th}$ ratios are high $(>20)$ compared with values of one to two commonly found in natural waters and silicate rocks (Kaufman and Broecker, 1965; Stearns and Thurber, 1965). Hence, the influence of any extraneous 230 Th upon the $230 \mathrm{Th} / 234 \mathrm{U}$ ratios from which ages are calculated should be small. (3) The 234 $\mathrm{U} / 238 \mathrm{U}$ ratios of $1.105 \pm 0.028$ and $1.102 \pm$ 0.026 are consistent with Th ages of 124 and $144 \mathrm{ka}$, considering the rate at which 234 $\mathrm{U} / 238 \mathrm{U}$ returns from its sea water of $1.14 \pm$ 0.015 (Ku et al., 1977) to its secular equilibrium value of 1.00 .

Corals have proven to be more suitable for age dating than mollusks because mollusk shells, unlike corals, often act as open systems that allow postdepositional migration of uranium and thorium isotopes (Kaufman et al., 1971). This generalization appears to be confirmed by the data in a study of the Nestor Terrace in southern California (Ku and Kern,

\section{METODOS EXPERIMENTALES Y RESULTADOS}

El método de fechado de materiales de carbonato marino mediante $\mathrm{Th} 230 / \mathrm{U} 234$ ha sido discutido en detalle (e.g. Thurber et al., 1965). El procedimiento que seguimos para la medicion de $234 \mathrm{U}, 238 \mathrm{U}, 230$ Th y $232 \mathrm{Th}$ es el descrito por $\mathrm{Ku}(1965,1968)$.

Se empleó espectrometría de partículas alfa utilizando un analizador de multicanal de pulso con detectores de silicón de estado sólido. La razón Calcita/Aragonita por intensidades pico de patrones de difracción de rayos-X. Las incertidumbres medidas representan las desviaciones estandar (un sigma) derivadas de las estadísticas de conteo (Tabla I). Las edades $230 \mathrm{Th} / 234 \mathrm{U}$ se calculan con la supocisión de que el carbonato inicialmente no contiene 230Th.

\section{DISCUSION DE RESULTADOS}

El siguiente criterio indica que los valores de $124 \pm 5$ y $144 \pm 7 \mathrm{ka}$ para las dos muestras de coral (Tabla I) representan bucnas estimaciones de edad para los depósitos de terrazas de Mulegé. (1) Los especímenes analizados estaban prácticamente libres de recristalización, como lo demuestra su minera$\log$ fa de $98 \%$ de aragonitas. (2) La razón 230 $\mathrm{Th} / 232$ Th es grande $(>20)$ comparada con los valores de uno a dos comúnmente encontrados de manera natural en agua y en rocas siliceas (Kaufman y Broecker, 1965; Steams y Thurber, 1965). Por lo tanto, la influencia de 230Th extraño en la razón $230 \mathrm{Th} / 234 \mathrm{U}$ con las que las edades se calculan será pequeña. (3) La razón $234 \mathrm{U} / 238 \mathrm{U}$ de $1.105 \pm 0.028$ y $1.102 \pm 0.026$ es consistente con las edades de Th de 124 y 144ka, considerando la razón en que $234 \mathrm{U} / 238 \mathrm{U}$ retorna desde los valores de $1.14 \pm 0.015$ en agua de mar (Ku et al., 1977) a su valor de equilibrio secular de 1.00 .

Los corales han probado ser mejores para datación de edad que los moluscos, debido a que las conchas de los moluscos, contrario a los corales, usualmente actúan 
Table I. Radiometric data on coral specimens from Mulegé Terrace Deposits.

Tabla I. Datos radiométricos de especímenes de coral de los depósitos de Terrazas de Mulegé.

\begin{tabular}{lccccl}
\hline Locality & $\mathrm{U}$ & \multicolumn{3}{c}{ Activity ratio } & 230Th/234U \\
\cline { 3 - 6 } no.* & $(\mathrm{ppm})$ & $234 \mathrm{U} / 238 \mathrm{U}$ & $230 \mathrm{Th} / 232 \mathrm{Th}$ & $230 \mathrm{Th} / 234 \mathrm{U}$ & age(ka) \\
\hline 3258 & $3.89 \pm 0.06$ & $1.10 \pm 0.03$ & $46.3 \pm 3.7$ & $0.75 \pm 0.02$ & $144 \pm 7$ \\
3261 & $2.84 \pm 0.05$ & $1.11 \pm 0.03$ & $21.9 \pm 1.2$ & $0.69 \pm 0.02$ & $124 \pm 5$ \\
\hline
\end{tabular}

Note: Specimens are coral species Porites califomica Verril. Calcite/aragonite ratios $<0.02$.

*Localities shown in Fig. 1

1974). Ages for the corals from the Nestor Terrace are significantly different from those of the tow mollusks from the same deposits (Table II).

We propose that the Mulegé Terrace deposits are contemporaneous with the raised corals reefs of $125,000 \mathrm{yr}$ age on the islands of Barbados and New Guinea (Mesollela $e t$ al., 1969; Bloom et al., 1974). These reefoid terraces have been widely taken to represent paleo-sea levels correlative with oxygen isotope stage $5 \mathrm{e}$ of deep-sea sediments (Shackleton and Opdyke, 1973). It should be noted that stage $5 \mathrm{e}$ of the marine 180 record is considered to have begun no earlier than 128ka (Broecker and van Donk, 1970; Imbrie et al., 1984). Thus, $144 \pm 7 \mathrm{ka}$ for sample 3258 (Table I), like other reported ages of 130-145ka for fossil corals from locations such as Timor, Atauro and the New Hebrides, and Jamaica (see Moore, 1982), appears to negate the correlation. The possibility of dual sea levels associated with the $125 \mathrm{ka}$ high sea stand has been discussed associated with the 125ka high sea stand has been discussed (Moore, 1982). The results of our study are consistent with, but do not serve as support to, such a possiblitiy; the ages of the two samples listed in Table I are indistinguishable at the $95 \%$ confidence level ( \pm 2 sigma) .

The Mulegé Terrace deposits can now be correlated with other terraces on the Pacific coast of the Baja California peninsula and southern California that have been similarly date by the uranium-series methods. como sistemas abiertos para una migración posdepositacionàl de isótopos de uranio y torio (Kaufman et al, 1971). Esta generalización parece ser confirmada por los datos del estudio de la Terraza Nestor en el sur de California (Ku y Kern, 1974). Las edades de los corales de la Terraza Nestor son significativamente diferentes de las de los dos moluscọs del mismo depósito (Tabla II).

Proponemos que los depósitos de las Terrazas de Mulegé son contemporáneos con los arrecifes de coral de 125,000 años de edad en las islas Barbados y Nueva Guinea (Mesollela et al., 1969; Bloom et al., 1974). Estas terrazas arrecifales representan paleo niveles del mar correlacionables con el estadio de isotopo de oxígeno 5e de sedimentos de mar profundo (Shackleton y Opdyke, 1973). Debe notarse que el estadio 5 e del récord marino 180 se considera que inició no antes de $128 \mathrm{ka}$ (Broecker y van Donk, 1970; Imbrie et al., 1984) entonces, $144 \pm 7 \mathrm{ka}$ para la muestra 3258 (Tabla I), como otras edades reportadas de 130-145ka para corales fósiles de localidades como Timor, Atauro, Las Nuevas Hebridas, y Jamaica (ver Moore, 1982) aparentan negar la correlación.

La posibilidad de una dualidad de niveles de mar asociada con el alto $125 \mathrm{ka}$ ha sido discutida (Moore, 1982). El resultado de nuestro estudio es consistente con eso pero no es una base para ello, aunque es una posibilidad; las edades de las dos muestras enlistadas en la Tabla I no pueden diferenciarse a un $95 \%$ de confianza ( \pm 2 sigma). 
Table II summarizes the published U-series ages from California and Baja California, Mexico. Ku and Kern (1974) suggested that widespread terrace cutting occurred along the west coast of California during the 5e high sea stand of Shackleton and Opdyke (1973). This hypothesis can now be extended to areas within the Gulf of California as it is clear that contemporaneous terraceformation was occurring in the Mulegé area. Other workers have cited occurrences of marine terraces thought to correspond to this widespread terrace-cutting event (Osmond et al., 1965; Veeh, 1966; Broecker and Van Donk, 1970; Ku et al., 1974; and in Baja California Ortleib, 1978).

\section{DEFORMATION}

The elevation of the shoreline angle (the line of intersection of the abrasion platform and the sea cliff; originally parallel to and approximately at sea level) in Mulegé is $12 \mathrm{~m}$ above the present shoreline angle. This measurement was made on the east side of $\mathrm{El}$ Sombrerito (SDSNH Loc. 3258, Fig. 1), the side most influenced by wave-cutting action. The measurement indicates a minor to moderate isostatic uplift rate of 4 to $5 \mathrm{~cm} / 1000 \mathrm{yr}$ since terrace formation. This value is calculated on the assumption that eustatic sea level during oxygen isotope stage $5 \mathrm{e}$ was situated $6 \mathrm{~m}$ above present sea level. This assumption is based on the suggestion for a $6 \pm 2 \mathrm{~m}$ eustatic sea stand during the Sangamon interglacial (e.g. Matthews, 1973; Bender et al., 1979; Stearns, 1976). The $6 \pm 2 \mathrm{~m}$ estimate was deduced from correlation of terraces on "stable oceanic islands" dated by Veeh (1966), and later by Ku et al. (1974) and by Neuman and Moore (1975). The Mulegé area has probably undergone no more than $8 \mathrm{~m}$ of isostatic uplift since 120 to $140 \mathrm{ka}$.

The method of measurement of terrace elevations in this study (from present shoreline angle to elevated terrace shoreline angle) utilizes the concept that the distance from the shoreline angle now being formed and the elevated terrace shoreline angle should be a more precise indicator of uplift. We recommend that when possible, future measurements be made from the present shoreline angle rather than sea level to eliminate
Las Terrazas de Mulegé pueden ser ahora correlacionadas con otras terrazas de la costa del Pacífico de la península de Baja California y del sur de California que han sido fechadas similarmente mediante los métodos Uranio-Torio. La Tabla II resume las edades de series de Uranio publicadas para California y Baja California, México. Ku y Kern (1974) sugieren que el corte de las terrazas ocurre a lo largo de la costa oeste de California durante el Se alto de Shackleton y Opdyke (1973). Esta hipótesis puede ser extendida a áreas del Golfo de California dado que es claro que la formación de terrazas en Mulegé es contemporánea. Otros autores han citado la ocurrencia de terrazas marinas que corresponden a esta generación de cortes en terraza (Osmond et al., 1965; Veeh, 1966; Braecker y van Donk, 1970; Ku et al., 1974; y en Baja California, Ortleib, 1978).

\section{DEFORMACION}

La elevación del ángulo de la línea de costa (la línea de intersección entre la plataforma de abrasión y el nivel del mar; originalmente paralela y aproximada al nivel del mar) en Mulegé está a $12 \mathrm{~m}$ sobre el ángulo de la línea de costa actual. Esta medición fue realizada en la porción este de El Sombrerito (SDSNH Loc. 3258, Fig. 1), el punto más influenciado por la acción erosiva del oleaje. La medición indica un reducido a moderado ascenso de 4 a $5 \mathrm{~cm} / 1000$ años desde la formación de la terraza. Este valor se calcula con la suposición de que el nivel eustático del mar durante el estado $5 \mathrm{e}$ del isótopo de oxígeno estaba situado $6 \mathrm{~m}$ sobre el nivel actual del mar. Esta suposición está basada en la sugestión de un nivel eustático de $6 \pm 2 \mathrm{~m}$ durante el interglaciar Sangamoniano (e.g. Matthews, 1973; Bender et al., 1979; Stearns, 1976). Los $6 \pm 2 \mathrm{~m}$ estimados se deducen de correlación de terrazas en "islas océanicas estables" fechadas por Veeh (1966), y posteriormente por Ku et al., (1974) y por Newman y Moore (1975). el área de Mulegé probablemente no ha estado sometida a un ascenso isostático de no más de $8 \mathrm{~m}$ desde 120 a $140 \mathrm{ka}$.

El método para medir la elevación de las terrazas en este estudio (a partir del ángulo de la línea de costa actual al ángulo de línea de 
Table II. Summary of published radiometric ages from California and Baja California, Mexico.

Tabla II. Resumen de edades radiométricas publicadas para California y Baja California, México.

\begin{tabular}{|c|c|c|c|}
\hline Terrace & $\begin{array}{l}\text { Dated } \\
\text { Fossils(s) }\end{array}$ & Age (ka)* & Reference ${ }^{* *}$ \\
\hline \multicolumn{4}{|l|}{ California } \\
\hline \multirow[t]{3}{*}{$\begin{array}{l}\text { First Terrace, San Pedro } \\
\text { (Palos Verdes Sand) }\end{array}$} & $\begin{array}{l}3 \text { mollusks } \\
7 \text { mollusks }\end{array}$ & $\begin{array}{c}115 \pm 10-160 \pm 15 \\
95 \pm 15-130 \pm 20\end{array}$ & $\begin{array}{l}\mathbf{a} \\
\mathbf{b}\end{array}$ \\
\hline & $>20$ mollusks & $120-140^{* * *}$ & $\mathbf{b}$ \\
\hline & 7 mollusks & $70 \pm 15-110 \pm 15$ & c \\
\hline \multicolumn{4}{|l|}{ Santa Monica Mountains } \\
\hline Dume Terrace & 7 mollusks & $95 \pm 25-112 \pm 15$ & c \\
\hline Coral Terrace & 3 mollusks & $115 \pm 15-154 \pm 30$ & c \\
\hline \multirow[t]{2}{*}{ Cayucos } & 1 coral & $124 \pm 27$ & $\mathbf{d}$ \\
\hline & 1 mollusk & $97 \pm 24$ & d \\
\hline \multicolumn{4}{|l|}{ San Nicolas Island } \\
\hline Terrace $1(13-17 \mathrm{~m})$ & 1 coral & $90 \geq 120$ & e \\
\hline Terrace $2(24-26 m)$ & 1 coral & $87 \pm 12-120 \pm 20$ & $\mathbf{e}$ \\
\hline \multicolumn{4}{|l|}{ Santa Cruz } \\
\hline 27-30m Terrace & 5 mollusks & $68 \pm 10-100 \pm 7$ & f \\
\hline \multicolumn{4}{|l|}{ San Diego } \\
\hline \multirow[t]{2}{*}{ Nestor Terrace } & 3 corals & $109 \pm 6-131 \pm 8$ & $\mathbf{g}$ \\
\hline & 2 mollusks & $84 \pm 6-93 \pm 3$ & $\mathbf{g}$ \\
\hline Lower terrace & 2 mollusks & $100 \pm 6-120 \pm 10$ & $\mathbf{g}$ \\
\hline \multicolumn{4}{|l|}{ Baja California Mexico } \\
\hline \multirow[t]{2}{*}{ Puerto Magdalena } & 1 coral & $118 \pm 12$ & h \\
\hline & 1 echinoid & $128 \pm 9$ & h \\
\hline Santa Margarita Island & 2 echinoids & $108 \pm 8-113 \pm 6$ & $\mathrm{~h}$ \\
\hline Mulegé (this study) & 2 corals & $124 \pm 6-144 \pm 7$ & \\
\hline
\end{tabular}

*Based on $230 \mathrm{Th} /{ }^{234} \mathrm{U}$ measurements, except first reference b(He/U age).

**a: thurber (1965); b: Fanale and Schaeffer (1965); c: Szabo and Rosholt (1969); d: Veeh and Valentine (1964; recalculated by Ku and Kern, 1974); e: valentine and Veeh (1969); f: Bradley and addicott (1968; data of Blanchard et al., 1967); g: Ku and Kern (1974); h: Omura et al. (1979).

$* * * 230 \mathrm{Th} / 234 \mathrm{U}$ ages measured by Broecker, Kaufman, and Thurber. 
variance, standardize data, and facilitate reproducibility of results.

\section{ACKNOWLEDGEMENTS}

Financial support by the Climate Dynamics Program, National Science Foundation Grant ATM-8514472 is gratefully acknowledged. J.P. Kern of San DiegoState University and Thomas Demere of the San Diego Natural History Museum offered helpful discussion during the preparation of this manuscript. C.A. Nelson of University of California, Los Angeles critically reviewed the paper.

\section{LITERATURA CITADA}

Ashby, J.R. (1984) Stratigraphy and Paleoecology of the Mulege Estuary, Baja California Sur, Mexico: [Senior Thesis] San Diego State University, San Diego, California, 49pp.

Ashby, J.R., and Minch, J.A. (1984) Late Pleistocene Molluscan Paleoenvironments of the Mulege Embayment, Baja California Sur, Mexico: American Association of Petroleum Geologists Society of Exploration Geophysicists - Society of Economic Pateontologists and Mineralogists, Pacific Sections, 59th Annual Meeting, Abstracts with Programs.

Ashby, J.R. and Minch, J.A. (1986) Late Tertiary Sedimentation and Molluscan Paleoecology of the Mulegé Embayment, Baja California Sur, Mexico. Revista de Ciencias Marinas.

Beal, C.H. (1948) Reconnaissance of the Geology and Oil Possibilities of Baja California, Mexico. Geol. Soc. Am. Memoir 31, 138pp.

Bender, M.L., Fairbanks, R.G., Taylor, F.W., Matthews, R.K., Goddard, J.G. and Broecker, W.S. (1979) Uranium-Series Dating of the Pleistocene Reef Tracts of Barbados, West Indies. Geol. Soc. Am. Bull. 90:577-594.

Blanchard, R.L., Chang, M.H. and Potratz, H.A. (1967) Uranium and Thorium Series Disequilibrium in Recent and Fossil Marine Molluscan Shells: J. of Geophys. Res. 72: 4745-4757. costa elevado de la terraza) utiliza el concepto de que la distancia desde el ángulo de línea de costa actual al de la terraza es un indicador de elevación mós preciso. Recomendamos que,en lo posible, las mediciones futuras se realicen con este método para eliminar varianza, estandarizar los datos y facilitar la reproducción de los resultados.

\section{AGRADECIMIENTOS}

Agradecemos el apoyo financiero de Climate Dynamics Program, National Science Foundation Grant ATM-8514472. A U.P. Kern de San Diego State University y Thomas Demere del San Diego Natural History Museum por su valiosa discusión durante la preparacion del manuscrito. A C.A. Nelson de University of California, Los Angeles, por la revisión critica del manuscrito.

Sergio Pou tradujo al español.

Bloom, A.L., Broecker, W.S., Chappell, J.M.A., Matthews, R.K. and Mesolella, KJ. (1974) Quaternary Sea Level Fluctuations on a Tectonic Coast: New Th 230/U 234 dates from the Huaon Peninsula, New Guinea. Quaternary Res. 4:185-205.

Bradley, W.C. and Addicott, W.O. (1968) Age of First Marine Terrace Near Santa Cruz, California. Geol. Soc. of Am. Bull. 79:1203-1210.

Broecker, W.S. and Van Donk, J. (1970) Isolation Changes, fce Volumes, and the 018 Record in Deep-Sea Cores. Rev. of Geophys. and Sp. Phys. 8:169-198.

Fanale, F.P. and Schaeffer, O.A. (1965) Helium-Uranium Ratios for Pleistocene and Tertiary Fossil Aragonites: Sci. 148:312-317.

Imbrie, J., Hayes, J.D., Markinson, D.G., McIntyre, A., Mix, A.C., Morley, J.J., Pisias, N.G., Prell, W.L. and Shackleton, N.J. (1984) The Orbital Theory of Pleistocene Climate: Support from a Revised Chronology of the Marine 0 Record, in Berger, A.L., et al. eds., Milaukovitch and Climate, Part 1: D. Reidel, Hingham, Mass:169-305. 
Kaufman, A., Broecker, W.S. (1965) Comparison of Th 230 and $C 14$ Ages for Carbonate Materials from Lakes Lahontan and Bonneville: J. of Geophy. Res. 70:4039-4054.

Kaufman, A. and Broecker, W.S., Ku, T.L. and Thurber, D.L. (1971) The Status of U-Series Methods of Mollusk Dating: Geochimica et Cosmochimica Acta 35:1155-1183.

Ku, T.L. (1965) An Evaluation of the U 234/U 238 Method as a Tool for Dating Pelagic Sediments: J. of Geophys. Res. 70:3457-3474.

Ku, T.L. (1968) Pa 231 Method of Dating Corals from Barbados Island: J. of Geophys. Res. 73:2271-2276.

$\mathrm{Ku}$, T.L. and Kern, J.P. (1974) Uranium-Series Age of the Upper Pleistocene Nestor Terrace, San Diego, California: Geol. Soc. of Am. Bull. 85:1713-1716.

Ku, T.L. Kimmel, M.A., Easton, W.H. and O'Neil, T.J. (1974) Eustatic Sea Level 120,000 Years Ago on Oahu, Hawaii. Sci. 183:959-962.

Ku, T.L. Knauss, K.G. and Mathieu, G.G. (1977) Uranium in the Open Ocean: Concentration and Isotopic Composition: Deep Sea Res. 24:1005-1017.

Matthews, R.K. (1973) Relative Elevation of Late Pleistocene High Sea Level Stands; Barbados Uplift Rates and Their Implications: Quaternary Res. 3:147-153.

McFall, C.C. (1968) Reconnaissance Geology of the Concepción Bay Area, Baja California, Mexico. Stanford Univ. Pub. in Geol. Sci. 10(5)25pp.

Mesollela, K.J., Matthews, R.K., Broecker, W.S., and Thurber, D.L. (1969) The Astronomical Theory of Climatic Changes: Barbados Data. J. Geol. 77:139-152.

Moore, W.S. (1982) Uranium Series Disequilibrium. In Ivanovich, M. and Harmon, R.S., eds., Applications to Environmental Problems, Oxford, Claredon Press: 481-496.

Neuman, A.C. and Moore, W.S. (1975) Sea Level Events and Pleistocene Coral Ages in the Northern Bahamas. Quaternary Res. 5:215-224.

Omura, A., Emerson, W.K. and Ku, T.L. (1979) Uranium-Series Ages of Echinoids and Corals from the Upper Pleistocene Magdalena Terrace, Baja California Sur, Mexico. The Nautilus 93(4):184-189.

Ortelib, L. (1978) Reconocimiento de las terrazas marinas cuaternarias en la parte central de Baja California: UNAM, Instituto de Geología, Revista 2:200-211.

Osmond, J.K., Carpenter, J.R. and Windom, H.L. (1965) $230 \mathrm{Th} / 234 \mathrm{U}$ Age of the Pleistocene Corals and Oolites of Florida. J.; Geophys. Res. 70:1843-1847.

Shakleton, N.J. and Opdyke, N.S. (1973) Oxygen Isotope and Paleomagnetic Stratigraphy of Equatorial Pacific Core V28-238: Oxygen Isotope Temperatures and Ice Volume on a $10^{4}$ and $10^{5}$ Year Schale. Quaternary Res. 3:39-55.

Stearns, C.E. (1979) Estimates of the Position of Sea Level Between 145,000 and 75,000 Years Ago. Quaternary Res. 6:445-449.

Stearns, C.E. and Thurber, D.L. (1965) Th-230/U-234 Dates of Late Pleistocene Marine Fossils from the Mediterranean and Moroccan Littorals. Quaternaria 7:23-42.

Szabo, B.J. and Rosholt, J.N. (1969) Uranium-Series Dating of Pleistocene Molluscan Shells from Southern California--An Open System Model. J. Geophys. Res. 7:3253-3260.

Thurber, D.L. (1965) The Dating of Mollusks from Raised Marine Terraces, in Schink, D.R., and Corless, J.T., eds., Symposium on Marine Geochemistry: Rhode Island Unversity Occasional Publications 3:1-27.

Thurber, D.L. Broecker, W.S., Blanchar, R.L. and Potratz, H.A. (1965) Uranium Series Ages of Pacific Atoll Coral: Science 149:55-58.

Valentine, J.W. and Veeh, H.H. (1969) Radiometric Ages of Pleistocene Terraces from San Nicolas Island, California: Geol. Soc. Am. Bull. 80:1415-1418. 
Ashby, James R. et al. - Uranium

Veeh, H.H. (1966) Th 230/U 238 and U 234/U 238 Ages of Pleistocene High Sea Level Stand: J. Geophy. Res. 71:3379-3386.
Veeh, H.H. and Valentine, J.W. (1967) Radiometric Ages of Pleistocene Fossils from Cayucos, California. Geol. Soc. Am. Bull. 78:547-550. 